\title{
2008 High-Flow Experiment at Glen Canyon Dam Benefits Colorado River Resources in Grand Canyon National Park
}

n March 5, 2008, the Department of
the Interior began a 60-hour high-
flow experiment at Glen Canyon Dam,
Arizona, to determine if water releases
designed to mimic natural seasonal
flooding could be used to improve
downstream resources in Glen Canyon
National Recreation Area and Grand
Canyon National Park. U.S. Geological
Survey (USGS) scientists and their coop-
erators undertook a wide range of physi-
cal and biological resource monitoring
and research activities before, during,
and after the release. Scientists sought
to determine whether or not high flows
could be used to rebuild Grand Canyon
sandbars, create nearshore habitat for
the endangered humpback chub, and
benefit other resources such as archaeo-
logical sites, rainbow trout, aquatic food
availability, and riverside vegetation.
This fact sheet summarizes research
completed by January 2010 .

\section{Background}

Glen Canyon Dam, which provides hydropower to customers in six states, regulates the Colorado River 15 miles upriver from Grand Canyon National Park, Arizona. Before the dam's completion in 1963, the Colorado River swelled in most years with spring snowmelt from the Rocky Mountains, producing floods and transporting large quantities of sand that created and maintained sandbars in Grand Canyon. These sandbars provide camping beaches for hikers and whitewater rafters, are sources of windborne sediment needed to protect archaeological resources from weathering and erosion, and create habitats used by native fish and other wildlife. For example, sandbars create backwaters - areas of low-velocity flow - that are thought to be used as rearing areas by the endangered humpback

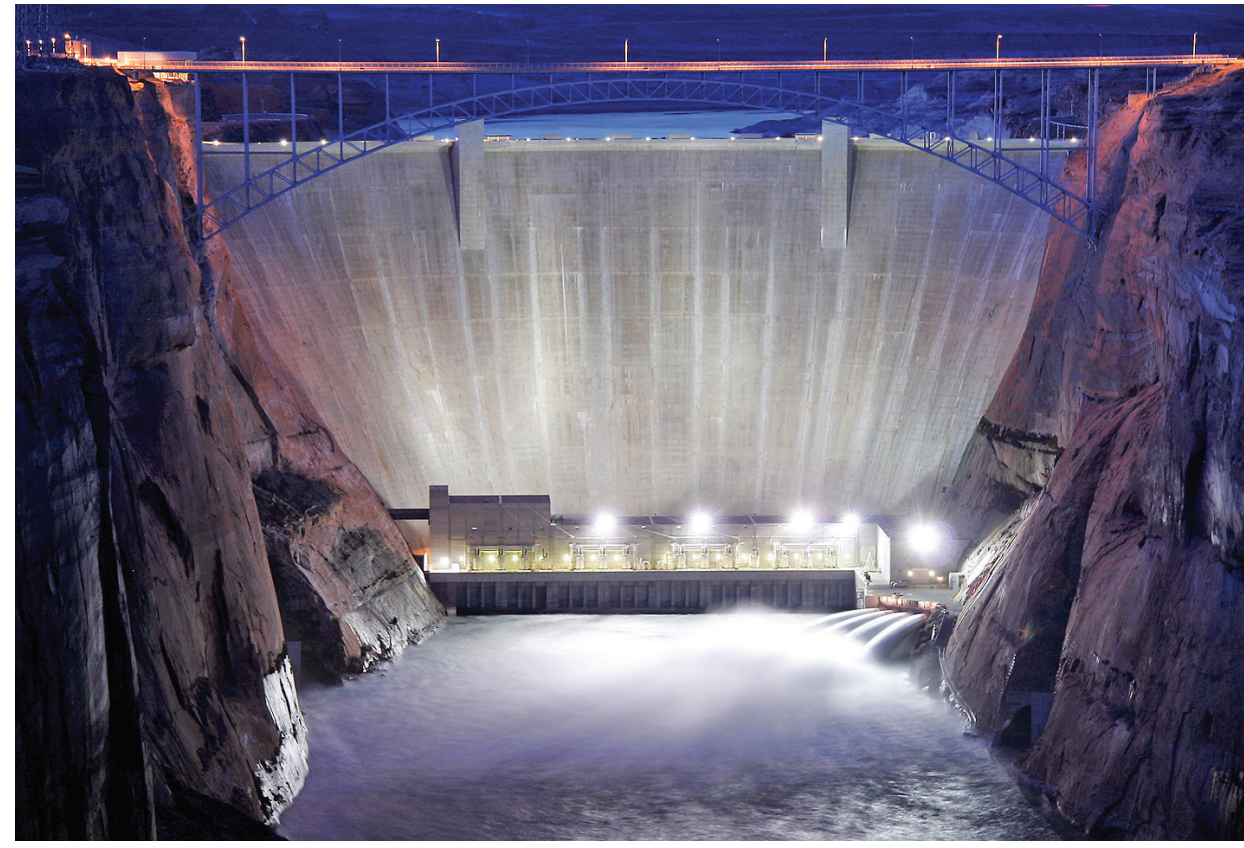

Glen Canyon Dam releases high flows of Colorado River water on the night of March 6, 2008. A highflow experiment was undertaken to determine if water releases designed to mimic natural seasonal flooding could be used to improve a wide range of downstream resources in Glen Canyon National Recreation Area and Grand Canyon National Park. (Photograph courtesy of T. Ross Reeve, Bureau of Reclamation.)

chub (Gila cypha) and other native fish. Today, the Colorado River downstream from Glen Canyon Dam usually runs clear because its reservoir, Lake Powell, traps all of the upstream sediment. Tributaries downstream from the dam, primarily the Paria and Little Colorado Rivers, provide Grand Canyon with 6 to $16 \%$ of its pre-dam sand supply.

Because of concerns about the effects of Glen Canyon Dam on downstream resources, the Grand Canyon Protection Act was enacted in 1992 "to protect, mitigate adverse impacts to, and improve the values for which Grand Canyon National Park and Glen Canyon National Recreation Area were established ..." In 1996, the Secretary of the Interior signed a formal decision that changed the operating rules of the dam, authorized experimental water releases from the dam, and established the Glen Canyon Dam
Adaptive Management Program. Adaptive management is a way to evaluate and revise management actions as new information becomes available through research, monitoring, and experimentation.

\section{High-Flow Experiment}

On March 5, 2008, the Secretary of the Interior pulled the levers at Glen Canyon Dam to release high flows into the Colorado River. Water was released through the powerplant and bypass tubes at the dam to a peak flow of approximately 41,500 cubic feet per second, about twice the normal peak flow, for 60 hours. This high-flow experiment (HFE) and two previous experiments in 1996 and 2004 were designed to mimic natural seasonal flooding.

U.S. Geological Survey (USGS) scientists and their cooperators conducted 


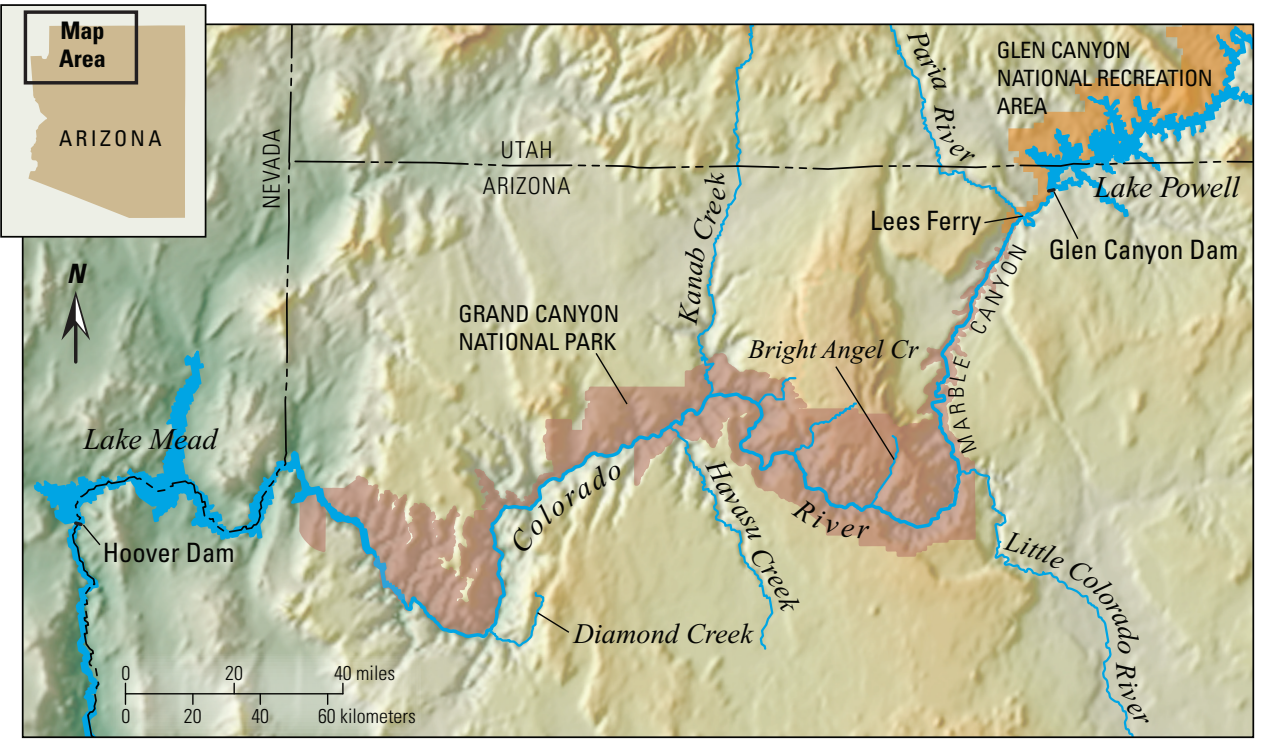

Map of the Colorado River below Glen Canyon Dam showing the river corridor between Lake Powell and Lake Mead reservoirs.

monitoring and research activities before, during, and after the 2008 HFE. This work focused on a wide range of questions, including: Are high flows capable of significantly rebuilding sandbars? Will windborne sand carried from rebuilt sandbars increase preservation potential at archaeological sites? Do such releases have the ability to create beneficial habitat for native fish? What effects do high flows have on riverside (riparian) vegetation, nonnative rainbow trout (Oncorhynchus mykiss), and the quality and abundance of aquatic foods that support native and nonnative fish?

\section{Sandbars}

The 2008 HFE resulted in widespread increases in the area and volume of sandbars, expansions of camping areas, and increases in the number and size of backwater habitats similar to or greater than those created by the 1996 and 2004 HFEs. During the 1996 HFE, sandbars increased in height, but at the expense of eroding the lower parts of preexisting sandbars; such erosion occurred to a much lesser extent during the 2008 HFE than in previous experiments. By October 2008, 6 months after the high-flow experiment, the new sandbars had been largely eroded by typical fluctuating-flow dam operations. However, median sandbar elevation was still slightly higher and backwater habitat was still slightly more abundant than in February 2008.
Building on what scientists learned from the 1996 and 2004 experiments, the 2008 HFE was timed to take advantage of multiple large sand inputs to the Colorado River in 2006 and 2007 from the Paria River. In November 2007, sand in the Colorado River reached levels typically seen only once in a decade. The results of the 2008 experiment reconfirmed that high flows are most effective when they are strategically timed to take advantage of tributary floods that supply new sand to the Colorado River downstream of the dam. However, the results of all three HFEs show that building sandbars throughout the river corridor in Grand Canyon National Park requires making more sand available than is typically delivered by tributaries annually. One possibility is to augment the sand delivered by tributaries with sand trapped behind the dam. Alternatively, the sand supply might be indirectly increased through the use of short-duration high flows following each average or greater tributary sand input. This approach would move new sand from the riverbed to sandbars before it can be carried downstream. Scientists have also learned that sandbars, backwaters, and other habitats are most efficiently built when larger quantities of finer grained sand are available in the Colorado River.

The key to the long-term maintenance of sandbars is to ensure that the frequency and timing of high flows are coordinated such that sandbar rebuilding exceeds the erosion that occurs between high flows. The rapid erosion of sandbars in the 6 months following the 2008 HFE highlights the importance of dam operations between high flows. For any annual release volume, the daily water release pattern and monthly volume of releases from Glen Canyon Dam directly affect the long-term sustainability of sandbars, because these factors strongly affect sandbar erosion and the retention of new sand from tributaries. Current and previous studies show that more stable and relatively lower monthly volume releases are most effective at limiting erosion of sandbars, retaining new sand, and improving access to backwaters by fish. However, the volume of water that must be released from Glen Canyon Dam annually is determined by basin hydrology and legal requirements to deliver water from the upper to the lower Colorado River Basin.

It may not be possible to rebuild and maintain sandbars over the long run solely through the manipulation of Glen Canyon Dam operations. Long-term experimentation that includes multiple, more frequent HFEs following tributary floods and that incorporates ongoing monitoring of intervening dam operations is required to resolve this question.

\section{Archaeological Sites}

In addition to investigating the effectiveness of restoring sandbars using high flows, scientists have also sought to determine whether or not new sandbars contribute to the preservation of archaeological sites in the Colorado River corridor. Many archaeological sites found near the river are buried by windborne sand that protects them from weathering and erosion. The greatest potential for moving new sand deposited by high flows inland toward archaeological sites occurs in the spring, when winds are stronger and precipitation is less likely to occur. The sandbars created by the March 2008 HFE were present during spring windy conditions, unlike sandbars created by the November 2004 HFE that were quickly eroded by experimental fluctuating flows in early 2005 .

Scientists monitored windblown sand movement following the March $2008 \mathrm{HFE}$ at nine archaeological sites. At two of nine study sites, spring and 

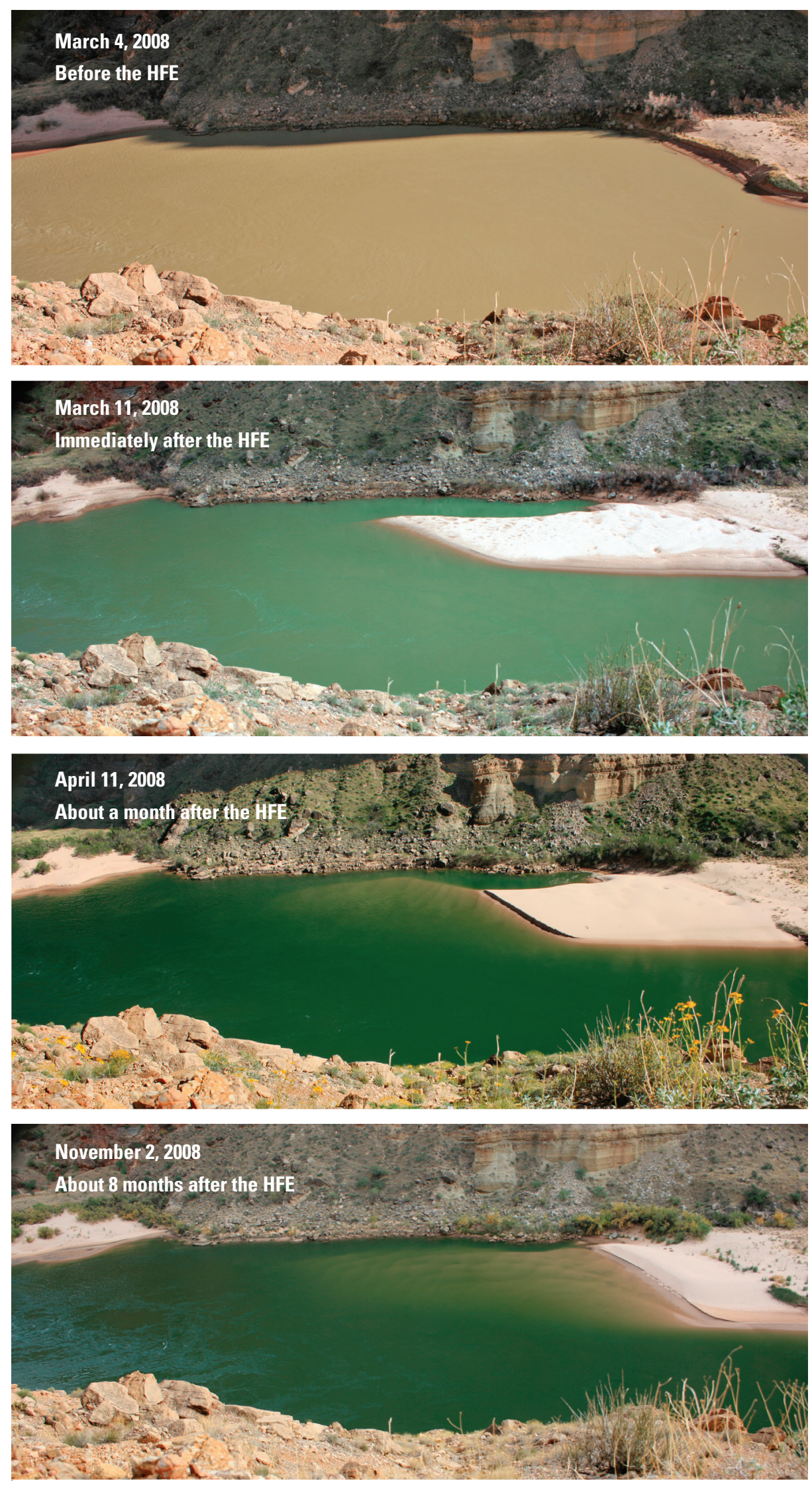

Matched photographs taken by a remote camera of a sandbar (Willie Taylor Camp) on the Colorado River about 45 miles downstream from Lees Ferry, Arizona. The series of photographs shows how the sandbar and its accompanying backwater (the area of water behind the sandbar thought to provide habitat for native fish) were affected by the 2008 high-flow experiment (HFE) and subsequent erosion in the 8 months following the HFE. All of the photographs were taken at about 4 P.M. at a water level associated with a flow rate of about 8,500 cubic feet per second from Glen Canyon Dam. summer winds reworked the new sandbars to form new dunes. The shape of the dunes in both cases indicated sand movement inland toward larger, well-established dune fields that contain archaeological sites. At the remaining seven sites, new sandbars did not result in sizeable dunes, and sand-transport rates after the 2008 experiment were similar to or lower than in previous years. These results were anticipated because much higher flows would be required to deposit sand in areas suitable for wind transport at some of the study sites.

\section{Riparian Vegetation}

The 2008 HFE provided an opportunity to examine the effects of high flows on riparian vegetation (plants living near a waterway), particularly the susceptibility of native riparian plant communities to the invasion of nonnative species such as tamarisk (Tamarix sp.). Riparian vegetation was generally buried by sand rather than being removed from the ground by the HFE. Tamarisk seedling germination was relatively minor (less than $2 \%$ of measured cover) 6 months after the experiment.

Conducting the 2008 HFE in March likely reduced successful tamarisk seedling germination because tamarisk produces flowers and seeds from April through September. Vegetative cover in areas above the highest water level reached during the HFE did not change significantly as a result of the March experiment. The continued coarsening of sandbars relative to pre-dam conditions and dam operations that wash finer sediment downstream appears to favor riparian species that grow through vegetative reproduction (clonal species), are adapted to partial burial, and that can persist in coarser sand, including many native species (for example, arrowweed (Pluchea sericea), seepwillow (Baccharis emoryi), and common reed (Phragmites australis)).

\section{Aquatic Food Web}

Determining how HFEs affect algae and aquatic invertebrates, which are the principal food sources for fish, was an important component of the 2008 experiment. In the clear Lees Ferry reach (a recreational trout fishery), which extends 15 miles downstream from Glen Canyon Dam to the Paria River confluence, the 2008 HFE temporarily decreased the 


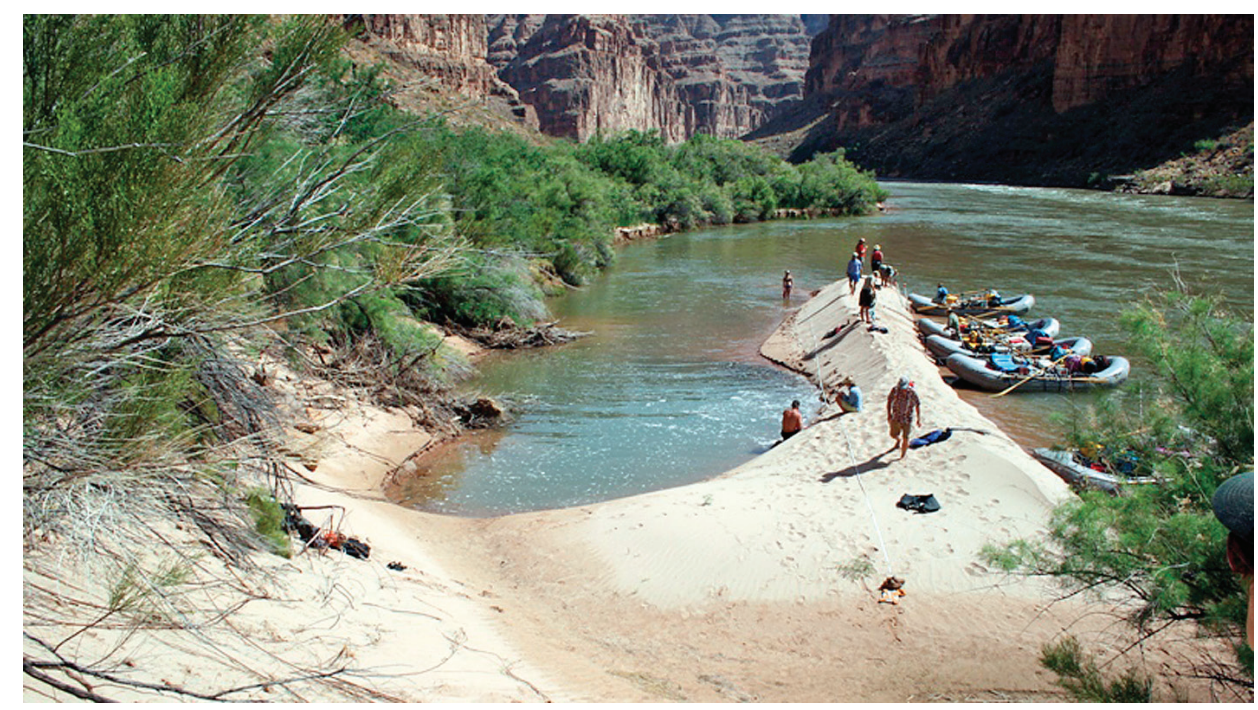

This sandbar in Grand Canyon was created as the result of the 2008 high-flow experiment at Glen Canyon Dam. To the left of the sandbar is a newly created backwater. Backwaters are areas of low-velocity flow that are thought to be used as rearing areas by the endangered humpback chub (Gila cypha) and other native fish. Sandbars also provide camping beaches for hikers and whitewater rafters. (Photograph courtesy of Joseph E. Hazel, Jr., Northern Arizona University.)

quantity of aquatic invertebrates. However, the relative quality of food sources increased because the HFE reduced the New Zealand mud snail (Potamopyrgus antipodarum) population by approximately $80 \%$ and increased midges and black flies. Midges and black flies are high-quality food items for trout. In contrast, the mud snail is a nonnative aquatic invertebrate that has invaded the Lees Ferry reach in large numbers and is considered a nuisance species because the snails cannot be digested when eaten by rainbow trout.

The mud snail population was reduced for at least 15 months after the 2008 HFE, whereas midges and black flies were more abundant after the HFE. The increased availability of high-quality food items may be partially responsible for the unusually high growth and survival rates of rainbow trout since the HFE. Research findings indicate that conducting high flows every 2 to 3 years may be an effective strategy for controlling mud snails.

\section{Rainbow Trout}

Scientists have sought to understand how high flows influence spawning and survival of early life stages of rainbow trout in the Lees Ferry reach. The March 2008 HFE resulted in a large increase in early survival of age-0 (fertilization to about 1 to 2 months from emergence) rainbow trout because of improved habitat conditions. Abundance of age- 0 trout in July 2008 was more than four times higher than had been expected.

Early survival was much higher for trout hatched about a month after the 2008 HFE than those hatched earlier in the year. Fish hatched a month after the HFE (about mid April) were not exposed to high flows and emerged into apparently better quality habitat. Scientists think that the 2008 experiment increased the tiny spaces between gravel on the river bottom and improved availability of high-quality food. As a result, recently emerged trout survived and grew better through the summer and fall. Trout abundance in 2009 was more than two times higher than expected given the estimated number of viable eggs deposited in that year, indicating that the effect of the high flows on young trout persisted for at least a year after the high flow.

Resource managers were concerned that high flows might cause downstream movement of rainbow trout from Lees Ferry to Grand Canyon, where nonnative trout prey on and compete with the endangered humpback chub and other native fish. Data collected before, during, and after the 2008 HFE indicate that trout did not move significantly as the result of the experiment. Additionally, surveys showed no change in the number of juvenile and adult trout before or after the experiment in the Lees Ferry reach.

\section{Conclusion}

On the basis of results from the March 2008 HFE, resources of the Colorado River in Grand Canyon appear to have generally benefitted from the high flows released from Glen Canyon Dam. Although sandbar building was widespread in response to the 2008 HFE, which occurred under highly sand-enriched conditions, these gains were short lived owing to erosion that occurred once releases from the dam resumed normal fluctuating-flow operations.

Planning future HFEs will benefit from the insights gained from both the March 2008 HFE and a comprehensive synthesis of the results from the 2008, 2004, and 1996 experiments that will be completed in 2010. Data from the 2008 experiment are also being used to advance development of sediment models and various aquatic-ecosystem models for the Colorado River. The sediment models will help scientists and managers determine the best frequency, timing, duration, and magnitude of future HFEs, whereas the ecosystem models will be used to evaluate factors contributing to changes in native and nonnative fish communities.

Theodore S. Melis,
David J. Topping,
Paul E. Grams,
David M. Rubin,
Scott A. Wright,
Amy E. Draut,
Joseph E. Hazel, Jr.,
Barbara E. Ralston,
Theodore A. Kennedy,
Emma Rosi-Marshall,
Josh Korman,
Kara D. Hilwig,
and Lara M. Schmit

\begin{tabular}{|}
\hline For more information contact: \\
U.S. Geological Survey \\
Southwest Biological Science Center \\
Grand Canyon Monitoring and Research Center \\
Flagstaff, AZ 86001 \\
928-556-7094 \\
This Fact Sheet and any updates to it are available \\
online at http://pubs.usgs.gov/fs/2010/3009/ \\
\hline
\end{tabular}

